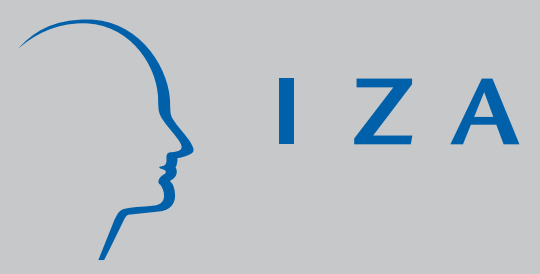

IZADP No. 2239

Corporate and Personal Income Tax Declarations

Laszlo Goerke

July 2006 


\title{
Corporate and Personal Income Tax Declarations
}

\author{
Laszlo Goerke
}

University of Tübingen, CESifo and IZA Bonn

\section{Discussion Paper No. 2239 July 2006}

IZA

P.O. Box 7240

53072 Bonn

Germany

Phone: +49-228-3894-0

Fax: +49-228-3894-180

Email: iza@iza.org

\begin{abstract}
Any opinions expressed here are those of the author(s) and not those of the institute. Research disseminated by IZA may include views on policy, but the institute itself takes no institutional policy positions.

The Institute for the Study of Labor (IZA) in Bonn is a local and virtual international research center and a place of communication between science, politics and business. IZA is an independent nonprofit company supported by Deutsche Post World Net. The center is associated with the University of Bonn and offers a stimulating research environment through its research networks, research support, and visitors and doctoral programs. IZA engages in (i) original and internationally competitive research in all fields of labor economics, (ii) development of policy concepts, and (iii) dissemination of research results and concepts to the interested public.
\end{abstract}

IZA Discussion Papers often represent preliminary work and are circulated to encourage discussion. Citation of such a paper should account for its provisional character. A revised version may be available directly from the author. 
IZA Discussion Paper No. 2239

July 2006

\section{ABSTRACT \\ Corporate and Personal Income Tax Declarations}

Decisions by firms and individuals on the extent of their tax payments have generally been treated as separate choices. Empirically, a positive relationship between corporate and personal income tax evasion can be observed. The theoretical analysis in this paper shows that a manager's decision on the firm's behaviour will be independent of his personal preferences if the gain from reducing corporate tax payments is certain, as in the case of tax avoidance. If, however, the firm evades taxes so that the manager's income depends on whether the firm's activities are detected or not, corporate and personal income tax evasion choices cannot be separated.

JEL Classification: $\quad \mathrm{H} 24, \mathrm{H} 25, \mathrm{H} 26$

Keywords: firms, individuals, tax evasion, uncertainty

Corresponding author:

Laszlo Goerke

University of Tübingen

Department of Economics

Melanchthonstr. 30

D-72074 Tübingen

Germany

E-mail: Laszlo.Goerke@uni-tuebingen.de 


\section{Introduction}

The decisions by firms, on the one hand, and individuals, on the other hand, on the extent of their tax payments have generally been investigated in isolation. However, the actions of firms are determined by individuals, i.e. managers or owners. The analytical separation between corporate tax avoidance or evasion choices and according decisions with respect to personal income taxes by the firms' decision-makers, therefore, relies on the implicit assumption that the determinants of the two actions are not related. However, if managers benefit from tax savings by firms, since their income is tied to after-tax profits, the separability assumption may not be warranted. According evidence is provided by Joulfaian (2000) who finds that American firms with assets of less than $\$ 10$ Mill. that are managed by corporate officers who evade personal income taxes are more likely to evade corporate taxes and exhibit more non-compliance than firms that are managed by non-tax evading individuals. Moreover, the extent of personal income misreported is related positively to the amount of understated income by firms.

The present paper analyses theoretically whether and how a manager's decision on corporate income tax avoidance or evasion is correlated with his or her choice of personal income tax evasion. If there is a systematic relationship, this will have important implications: first, from a theoretical perspective, modelling tax avoidance or evasion by firms as a decision on the optimal value of a single variable can yield inadequate predictions regarding the firms' behaviour. Second, from an empirical point of view, analyses of tax evasion or avoidance by firms are faced by an omitted variable bias, unless tax evasion behaviour of relevant decision makers is proxied adequately. Third, from a policy viewpoint, a unique relationship between personal and corporate income tax declarations represents a strong incentive for tax authorities to co-ordinate personal and corporate income tax audits.

The manager's choice of personal income tax evasion is modelled as a decision of a strictly risk-averse individual under uncertainty in a standard Allingham and Sandmo (1972) framework. Personal income is assumed to depend positively on after-tax profits. It turns out that the relationship between corporate and personal income tax declarations is crucially determined by the exact manner in which a firm's tax declarations affect its manager's income. Therefore, two basic cases are looked at: in the first, the net gain from reducing corporate income tax payments is certain. Such a setting can be interpreted as describing tax avoidance behaviour if this constitutes a costly but risk-less activity (Alm 1988, Cowell 1990a, p. 12f, Balestrino and Galmarini 2003, Marchese 2004). If, as in the second, the outcome resulting from reducing tax payments is uncertain, this can be viewed as evasion since illegal activities are punished with a positive probability. While tax avoidance may also involve uncertain 
returns (cf. Alm and McCallin 1990), this interpretation is ruled out in the present context, to clearly distinguish activities which reduce tax payments with certainty from tax evasion.

It is shown that corporate and personal income tax declarations will be independent in the case of corporate tax avoidance. This is because corporate avoidance maximises the firm's net profits and, hence, the manager's profit-related income. Since this income is the same in all states of the world, there is no gain to the manager from reducing the profit-related income to mitigate the risk which arises from personal income tax evasion. However, corporate income tax evasion decisions will generally be affected by personal income tax evasion choices, and vice versa. Such a linkage exists since corporate income tax evasion can be used to diversify the risk which personal income tax evasion entails. Accordingly, any variable which affects the attractiveness of personal income tax evasion alters the need to use corporate income tax evasion activities in order to reduce the variation in expected income. The nature of the relationship between personal and corporate income tax evasion cannot be predicted on the basis of the general model. Thus, a more restrictive setting is looked at in addition. In particular, it can be shown that if there is a perfect correlation of detection probabilities for personal and corporate income tax evasion, that is if detecting one evasion activity automatically implies being punished for the other as well, the amounts of evasion tend to be related inversely. Such choices are optimal because a perfect correlation of detection probabilities implies that an increase, for example, in personal income tax evasion will raise the utility loss due to insufficient corporate income declarations if evasion is detected, whereas the respective gains remain unaffected.

While the relationship between corporate and personal income tax declarations, be it avoidance or evasion, has not been looked at analytically, the consequences of extending an individual's choice beyond a simple tax evasion gamble have been investigated. Landskroner et al. (1990), for example, assume that an individual initially determines the fraction of available wealth which is invested in a risky or risk-less asset. Given this choice, the risk-averse individual decides how much of the certain income from human capital to declare to tax authorities. Lee (1995) and Wrede (1995) assume that a risk-averse individual determines how much wealth to invest in a risky asset at the outset. Then returns from investments become known. Finally, the amount of tax evasion is determined. Hence, uncertainty about the returns from investment is resolved prior to the evasion decision. Moreover, Yaniv (1999) investigates the simultaneous decision to evade taxes and to launder undeclared income, with laundering being equivalent to a reduction of the fine for evasion. In contrast to the present analysis, none of these papers focus on the nature of the link between the two tax evasion (or avoidance) decisions. Alm 
(1988) and Alm and McCallin (1990) investigate a joint decision about tax evasion and avoidance. In line with the assumption of the present paper, Alm (1988) views evasion as a decision under uncertainty, whereas avoidance is interpreted as (legal) non-payment of taxes involving certain costs. In contrast, Alm and McCallin (1990) model avoidance as yielding an uncertain return which differs in mean and variance from the return of evasion. Both papers look at personal income taxes and assume that an increase in, for example evasion, automatically reduces avoidance, for a given declaration of income to tax authorities. Finally, Martinez-Vazquez and Rider (2005) investigate optimal income tax evasion behaviour in a world in which individuals can under-declare income and overstate deductions.

The remainder of the paper is structured as follows: Section 2 describes the model. Section 3 looks at a setting in which the manager avoids corporate and evades personal income taxes. Section 4 allows for corporate tax evasion. Initially, uncorrelated detection probabilities for corporate and personal income tax evasion are assumed. Subsequently, the special case of correlated detection probabilities mentioned above is investigated. In all settings interior solutions are assumed. Moreover, an encompassing framework is employed in which the costs of avoidance can be (re-) interpreted as the penalty for evading taxes. Section 5 contains some concluding remarks.

\section{Model}

Suppose a strictly risk-averse, male ${ }^{1}$ manager, characterised by von-Neumann-Morgenstern preferences and the (indirect) utility function $\mathrm{u}, \mathrm{u}^{\prime}>0$, $\mathrm{u}^{\prime \prime}<0$, can take two decisions: (1) how much of his personal income and (2) the amount of profits - or corporate income - to declare to tax authorities as tax basis. The executive's personal income consists of a fixed salary I and a fraction $\mu>0$ of after-tax profits of the firm which he manages. This dependency of personal income on profits ensures that the manager can benefit from lower tax payments by the firm. If the manager's income depended solely on gross-of-tax profits, he would have no incentives for reducing the firm's tax payments. Gross personal income $\Psi$ is reduced by personal income tax payments, which equal the product of the amount of personal income $\mathrm{Y}$ which is declared to tax authorities and a linear tax rate t. Personal income tax evasion is detected with probability p. In such a case, a fine $\mathrm{F}[\mathrm{t}(\Psi-\mathrm{Y})]$ has to be paid, which increases at a (weakly) increasing rate

\footnotetext{
${ }^{1}$ Although there is evidence that the incidence and volume of tax evasion is greater among males than females (Baldry 1987), it is not overwhelming (Alm 1999). Thus, the assumption is made for expositional purposes only.
} 
with the amount of taxes evaded $\mathrm{t}(\Psi-\mathrm{Y})$. Moreover, the marginal fine $\mathrm{F}^{\prime}$ must exceed unity to ensure an interior solution. Hence, $F^{\prime}>1$ and $F^{\prime \prime} \geq 0$ are assumed to hold. ${ }^{2}$

Pre-tax profits $\Pi$ are exogenous. ${ }^{3}$ The manager declares a level of profits $\Phi$ to tax authorities, on which a corporate income or profit tax rate $s>0$ is applied. The function $C[(\Pi-\Phi) s]$ represents either certain costs of avoidance or, alternatively, the fine if caught evading taxes, where $C^{\prime}, C^{\prime \prime}>0$ for $\Pi-\Phi>0$ is assumed. Fixed (marginal) costs of an audit or of zero tax avoidance could prevent the manager from engaging in evasion or avoidance activities. Since, however, the focus is on interior solutions, such an outcome can be neglected and $\mathrm{C}(0)=\mathrm{C}^{\prime}(0)$ $=0$ is presumed. If profit tax evasion is fined, this will take place with probability $\mathrm{q}$, being independent of the probability p, unless assumed otherwise in Section 4.2.

If both evasion choices entail two possible outcomes which are determined independently being caught evading taxes and being successful doing so -, the manager's actions can result in four possible states $i, i=1,2,3,4$. Since, moreover, the manager's choices of corporate and personal income declarations cannot differ in the four states, given simultaneous choices of income declarations, the expected utility $\mathrm{V}$ of the manager can be expressed as: ${ }^{4}$

$$
\begin{aligned}
\mathrm{V}=(1-\mathrm{p}) \mathrm{qu}[\mathrm{I}+\mu(\Pi-\Phi \mathrm{s}-\mathrm{C}[(\Pi-\Phi) \mathrm{s}])-\mathrm{Yt}] \\
\quad+\mathrm{pqu}\left[\mathrm{I}+\mu(\Pi-\Phi \mathrm{s}-\mathrm{C}[(\Pi-\Phi) \mathrm{s}])-\mathrm{Yt}-\mathrm{F}\left[\left(\Psi_{\mathrm{A}}-\mathrm{Y}\right) \mathrm{t}\right]\right] \\
\quad+(1-\mathrm{p})(1-\mathrm{q}) \mathrm{u}[\mathrm{I}+\mu(\Pi-\Phi \mathrm{s})-\mathrm{Yt}] \\
\quad+\mathrm{p}(1-\mathrm{q}) \mathrm{u}\left[\mathrm{I}+\mu(\Pi-\Phi \mathrm{s})-\mathrm{Yt}-\mathrm{F}\left[\left(\Psi_{\mathrm{B}}-\mathrm{Y}\right) \mathrm{t}\right]\right]
\end{aligned}
$$

In equation (1) $\Psi_{\mathrm{A}}:=\mathrm{I}+\mu(\Pi-\Phi \mathrm{s}-\mathrm{C}[(\Pi-\Phi) \mathrm{s}])$ and $\Psi_{\mathrm{B}}:=\mathrm{I}+\mu(\Pi-\Phi \mathrm{s})$ define taxable personal income. The fixed salary I will be set equal to zero in the subsequent analysis since its magnitude does not affect the correlation between personal and corporate income declarations. As indicated above, two basic cases will be looked at:

\footnotetext{
${ }^{2}$ In general, the impact of changes in income or tax rates on evasion behaviour depends on the specification of the fine function (see Yitzhaki 1974, Andreoni et al. 1998, or Slemrod and Yitzhaki 2002). The relationship between optimal corporate and personal income declarations is not altered by assuming the penalty for evasion to be a function of undeclared income instead of taxes evaded.

${ }^{3}$ This assumption is made for analytical simplicity only and does not affect results. To illustrate, assume that profits are a function of some variable $\mathrm{x}$ which the manager can determine. If variations in $\mathrm{x}$ do not change the manager's utility, except for changes in profits, first maximising profits and then selecting income declarations will always be superior to any other combination of $\mathrm{x}$ and income declarations. Profits may obviously not be chosen maximally if achieving a profit maximum were costly for the manager. The interaction of tax evasion and effort choices in a principal-agent setting is investigated by Chen and Chu (2005), while Crocker and Slemrod (2005) examine implications for the tax enforcement structure in a related framework.

${ }^{4}$ If sequential choices of income declarations are presumed, the findings summarised below continue to hold. Therefore, sequential choices are not looked at further.
} 
1. Corporate income tax avoidance. In this setting (Section 3), $q=1$ holds.

2. Corporate and personal income taxes are evaded. In this case (Section 4 ), $0<\mathrm{q}<1$ applies.

\section{Corporate Income Tax Avoidance}

Modelling the choice of corporate income tax declarations as a decision under certainty is incompatible with the usual notion of tax evasion activities as being a risky endeavour which can result in having to pay a penalty. Thus, the existence of certain gains is assumed to imply tax avoidance. The decisive feature of tax avoidance in the present analysis is, therefore, not the legal evaluation of according activities but whether or not its net gain is the same, irrespective of the outcome of the personal income tax evasion gamble. Maximising V with respect to profit declarations $\Phi$ and personal income statements $\mathrm{Y}$, using $\Psi_{\mathrm{B}}=\Psi:=$ $\mu(\Pi-\Phi \mathrm{s}-\mathrm{C}[(\Pi-\Phi) \mathrm{s}]), \quad \theta_{1}:=\mu(\Pi-\Phi \mathrm{s}-\mathrm{C}[(\Pi-\Phi) \mathrm{s}])-\mathrm{Yt}, \quad$ and $\quad \theta_{2}:=\theta_{1}-\mathrm{F}[(\Psi-\mathrm{Y}) \mathrm{t}]$ yields:

$$
\begin{aligned}
& \frac{\partial \mathrm{V}}{\partial \Phi}=\mu \mathrm{s}\left(\mathrm{C}^{\prime}[(\Pi-\Phi) \mathrm{s}]-1\right)\left\{(1-\mathrm{p}) \mathrm{u}^{\prime}\left[\theta_{1}\right]+\mathrm{pu}^{\prime}\left[\theta_{2}\right]\left(1-\mathrm{F}^{\prime}[(\Psi-\mathrm{Y}) \mathrm{t}] \mathrm{t}\right)\right\}=0 \\
& \frac{\partial \mathrm{V}}{\partial \mathrm{Y}}=-\mathrm{t}\left\{(1-\mathrm{p}) \mathrm{u}^{\prime}\left[\theta_{1}\right]+\mathrm{pu}^{\prime}\left[\theta_{2}\right]\left(1-\mathrm{F}^{\prime}[(\Psi-\mathrm{Y}) \mathrm{t}]\right)\right\}=0
\end{aligned}
$$

An optimal choice of Y according to (3) implies that the expression in curly brackets in (2) is positive, since $F^{\prime}[(\Psi-Y) t]>1$. Therefore, a simultaneous validity of the two first-order conditions requires $\mathrm{C}^{\prime}[(\Pi-\Phi) \mathrm{s}]=1$. The second derivatives of $\mathrm{V}$ are negative.

$$
\begin{gathered}
\frac{\partial^{2} \mathrm{~V}}{\partial \mathrm{Y}^{2}}=(1-\mathrm{p}) \mathrm{u}^{\prime \prime}\left[\theta_{1}\right] \mathrm{t}^{2}+p u^{\prime \prime}\left[\theta_{2}\right]\left(\mathrm{t}-\mathrm{F}^{\prime}[(\Psi-\mathrm{Y}) \mathrm{t}] \mathrm{t}\right)^{2}-\mathrm{pu}^{\prime}\left[\theta_{2}\right] \mathrm{F}^{\prime \prime}[(\Psi-\mathrm{Y}) \mathrm{t}] \mathrm{t}^{2}<0 \\
\frac{\partial^{2} \mathrm{~V}}{\partial \Phi^{2}}=-\mu \mathrm{s}^{2} \mathrm{C}^{\prime \prime}[(\Pi-\Phi) \mathrm{s}]\left\{(1-\mathrm{p}) \mathrm{u}^{\prime}\left[\theta_{1}\right]+\mathrm{pu}^{\prime}\left[\theta_{2}\right]\left(1-\mathrm{F}^{\prime}[(\Pi-\Psi) \mathrm{t}] \mathrm{t}\right)\right\}<0
\end{gathered}
$$

Furthermore, the cross derivative $\partial^{2} \mathrm{~V} /(\partial \Phi \partial)$ and the product of $\partial^{2} \mathrm{~V} /(\partial \Phi \partial \mathrm{x})$ and $\partial^{2} \mathrm{~V} /(\partial \mathrm{Y} \partial \mathrm{x})$ for any variable $\mathrm{x}, \mathrm{x}=\mathrm{t}, \mathrm{p}, \mathrm{s}, \Pi, \mathrm{C}^{\prime}, \mathrm{C}, \mathrm{F}^{\prime}, \mathrm{F}^{5}$ are zero, given optimal choices in accordance with equations (2) and ( 3 ). The results can be summarised as:

\footnotetext{
${ }^{5}$ Separate changes in $\mathrm{C}^{\prime}$ and $\mathrm{C}$ imply that the marginal costs of tax avoidance can be altered without affecting its level and vice versa. This is feasible for a cost function $\mathrm{C}=\mathrm{C}_{0}+\mathrm{C}_{1}[(\Psi-\mathrm{Y}) \mathrm{t}], \mathrm{C}_{0}, \mathrm{C}_{1}>0$. An analogous argument applies for the penalty function $\mathrm{F}[(\Psi-\mathrm{Y}) \mathrm{t}]$ for personal income tax evasion and its parameters $\mathrm{F}^{\prime}$ and $\mathrm{F}$.
} 


\section{Proposition 1}

A strictly risk-averse manager's decision on corporate income tax avoidance will be unrelated to his choice of personal income tax evasion.

Proposition 1 can be explained as follows: variations in corporate and personal income declarations affect the manager's expected utility in a fundamentally different manner. This is the case because any variation in personal income declarations directly alters the amount of personal income taxes paid, whereas a change in profit declarations and, hence, in profitrelated income may only change personal income tax payments if tax evasion is detected. Therefore, the marginal expected utility of higher profit declarations is still positive, given an optimal choice of personal income declarations, as a comparison of the expressions in curly brackets in equations (2) and (3) shows. The best the manager can do is to maximise profitrelated earnings, that is after- (profit-) tax profits, by equalising the firm's marginal costs and gains of profit declarations, implying $C^{\prime}[(\Pi-\Phi) s]=1$.

Proposition 1, hence, implies a further neutrality result in the analysis of tax declarations by firms. Not only can the decision about economic activity be separated from the tax evasion decision under a variety of circumstances, ${ }^{6}$ but moreover, the choice on personal income tax evasion can be isolated from the decision about profit tax declarations if the latter represents a risk-less, albeit costly activity. Accordingly, the manager's personal preferences and, particularly, his degree of risk-aversion are without impact on the optimal amount of corporate income tax avoidance.

\section{Corporate Income Tax Evasion}

\subsection{General Case}

Assume now that the reduction of corporate income tax payments entails the risk of being penalised for tax evasion. As profit and personal income declarations are determined simultaneously, the first-order conditions resulting from the maximisation of $\mathrm{V}$ in equation (1) are given by:

$$
\begin{array}{r}
\frac{\partial \mathrm{V}}{\partial \Phi}=\mu \mathrm{s}\left(\mathrm{C}^{\prime}[(\Pi-\Phi) \mathrm{s}]-1\right) \mathrm{q}\left\{(1-\mathrm{p}) \mathrm{u}^{\prime}\left[\theta_{1}\right]+\mathrm{pu}^{\prime}\left[\theta_{2}\right]\left(1-\mathrm{F}^{\prime}\left[\left(\Psi_{\mathrm{A}}-\mathrm{Y}\right) \mathrm{t}\right] \mathrm{t}\right)\right\} \\
-\mu \mathrm{s}(1-\mathrm{q})\left\{(1-\mathrm{p}) \mathrm{u}^{\prime}\left[\theta_{3}\right]+\mathrm{pu}^{\prime}\left[\theta_{4}\right]\left(1-\mathrm{F}^{\prime}\left[\left(\Psi_{\mathrm{B}}-\mathrm{Y}\right) \mathrm{t}\right] \mathrm{t}\right)\right\}=0
\end{array}
$$

\footnotetext{
${ }^{6}$ According results and exceptions are analysed by Wang and Conant (1988), Yaniv (1995, 1996), Marelli (1984), Marelli and Martina (1988), Lee (1998), and Panteghini (2000), inter alia.
} 


$$
\begin{aligned}
\frac{\partial \mathrm{V}}{\partial \mathrm{Y}}=-\mathrm{tq}\left\{(1-\mathrm{p}) \mathrm{u}^{\prime}\left[\theta_{1}\right]+\mathrm{pu} \mathbf{u}^{\prime}\left[\theta_{2}\right]\left(1-\mathrm{F}^{\prime}\left[\left(\Psi_{\mathrm{A}}-\mathrm{Y}\right) \mathrm{t}\right]\right)\right\} \\
-\mathrm{t}(1-\mathrm{q})\left\{(1-\mathrm{p}) \mathrm{u}^{\prime}\left[\theta_{3}\right]+\mathrm{pu}^{\prime}\left[\theta_{4}\right]\left(1-\mathrm{F}^{\prime}\left[\left(\Psi_{\mathrm{B}}-\mathrm{Y}\right) \mathrm{t}\right]\right)\right\}=0
\end{aligned}
$$

for $\theta_{1}:=\mu(\Pi-\Phi \mathrm{s}-\mathrm{C}[(\Pi-\Phi) \mathrm{s}])-\mathrm{Yt}>\theta_{2}:=\theta_{1}-\mathrm{F}\left[\left(\Psi_{\mathrm{A}}-\mathrm{Y}\right) \mathrm{t}\right], \theta_{1}<\theta_{3}:=\mu(\Pi-\Phi \mathrm{s})-$ $\mathrm{Yt}>\theta_{4}:=\theta_{3}-\mathrm{F}\left[\left(\Psi_{\mathrm{B}}-\mathrm{Y}\right) \mathrm{t}\right]$, and $\Psi_{\mathrm{B}}:=\mu(\Pi-\Phi \mathrm{s})>\Psi_{\mathrm{A}}:=\mu(\Pi-\Phi \mathrm{s}-\mathrm{C}[(\Pi-\Phi) \mathrm{s}])$.

The optimal choice of corporate income tax evasion $\Phi$ will be independent of personal income tax evasion behaviour if $\partial^{2} \mathrm{~V} /(\partial \Phi \partial \mathrm{Y})=0$. However, this cross-derivative cannot be signed. Therefore, without further structure on the optimisation problem, the relationship between optimal personal and corporate income tax evasion and the impact of exogenous variables on this relation cannot be determined. The results are summarised in:

Proposition 2

Optimal corporate and personal income tax evasion activities will generally not be independent. An unambiguous correlation in the amounts of personal and corporate income tax evasion does not exist.

The intuition for the interdependence between corporate and personal income tax choices is the following: the manager's expected utility from a personal income tax declaration $\mathrm{Y}$ varies with the amount of corporate income which the firm actually has to pay to tax authorities, and vice versa. Therefore, optimal choices of $\mathrm{Y}$ and $\Phi$ are not independent. This contrasts with a situation in which the net gain from corporate income declarations is certain because in such a setting variations in corporate income declarations alter the payoff from personal income tax evasion by a multiple of 1 - $\mathrm{C}^{\prime}$ and, hence, proportionally. If the returns from corporate income declarations are uncertain, however, variations in corporate income declarations will alter the payoff from personal income tax evasion by $\mu$ s - or a multiple thereof - if corporate income tax evasion is not detected and by $\mu \mathrm{sC}^{\prime}$ - or a multiple - if corporate tax evasion is detected. By adjusting personal income tax declarations the manager can, therefore, reduce the magnitude of income variations in exchange for a reduction in expected income. Accordingly, the fundamental reason for the correlation between personal and corporate income declarations to tax authorities in the present set-up is that corporate tax payments affect the manager's personal tax liability in different states to a differential extent.

It has to be emphasised, though, that the direction of the correlation between the amount of corporate and personal income tax evasion is ambiguous. This is the case because the manager will attempt to diversify risk but will also obtain a higher expected income when he chooses to 
take a (greater) second risk. The net impact of adding the second risk (personal income tax evasion) on the first (corporate income tax evasion) is uncertain. Given four possible outcomes of the tax evasion gamble, it is not feasible to determine general conditions, for example with respect to the attitude towards risk, which allow establishing whether the income or substitution effect of a change in an exogenous variable dominates.

The finding summed up in Proposition 2 is supportive of the conjecture by Joulfaian (2000, p. 698) that "managerial preferences, such as attitude towards risk or simply intrinsic dishonesty, controlling for tax and detection rates, may determine a firm's compliance behaviour." His empirical finding "that firms with managers who have understated personal income taxes experience greater noncompliance" (p. 700) is a feasible outcome which may be derived from the general model. However, the framework also allows for the opposite correlation.

Formally, tax evasion entailing an uncertain outcome is equivalent to an according behaviour with a certain payoff, making use of an appropriately defined cost-of-evasion function and the concept of the certainty equivalent (cf. Cowell 1990b). This equivalence clarifies that it is not the uncertain outcome of corporate income tax evasion per se that creates a link between the optimal amounts of personal and corporate income declarations. Such a relationship will generally exist if the (expected or certain) costs (or gains) of reducing the payment of one tax are affected by the optimal amount of the other tax paid. In the model under consideration, corporate income tax payments affect personal income, but personal income tax payments do not alter profits. Section 3 assumes certain costs of corporate tax avoidance in addition. Thus, the payoff from personal income tax evasion has no repercussions on the costs or gains from corporate tax avoidance. In Section 4.1, the payoff from corporate income tax evasion varies with the extent of personal income tax evasion. In the above set-up, this effect arises because of the uncertainty which corporate income tax evasion causes. However, the same qualitative impact will occur if the costs of corporate income tax evasion are certain, as long as a cost-ofcorporate-income-tax-evasion-function depends on the extent of personal income tax evasion.

\subsection{Special Case: Correlation of Detection Probabilities}

To circumvent the (analytical) ambiguity with respect to the direction of the relationship between personal and corporate income tax evasion as summarised in Proposition 2, suppose that detecting corporate income tax evasion induces tax authorities to investigate the personal income tax declaration of the manager as well. Alternatively, it may be assumed that a manager who is detected evading personal income taxes can be certain that the tax declaration of the 
company will be inspected too. In either of the cases, the number of possible states will be reduced from four to three. While the amounts of personal and corporate income tax evasion continue to be related, the direction of the correlation remains ambiguous. This is the case because the fundamental features of a world with four possible states continue to apply in a world with three states. That is, the payoff from varying one evasion activity affects the costs (or gains) from the other, and vice versa.

To resolve the ambiguous relationship between personal and corporate income tax evasion, presume further that detection probabilities are perfectly correlated. Such a perfect correlation yields two outcomes $(\mathrm{i}=2,3)$ only and can be modelled by defining $0<\mathrm{z}:=\mathrm{pq}<1$ and $1-\mathrm{z}$ $:=(1-p)(1-q)$. Situations in which either only the manager personally or solely the firm are fined cannot arise so that $u\left(\theta_{1}\right)$ and $u\left(\theta_{4}\right)$ are constant and $u\left(\theta_{1}\right)=u\left(\theta_{4}\right)=u^{\prime}\left(\theta_{1}\right)=u^{\prime}\left(\theta_{4}\right)=0$ can be assumed in equations (1), (5), and (6). The first-order conditions (5) and (6) then become:

$$
\begin{aligned}
& \frac{\partial \mathrm{V}}{\partial \Phi}=0 \Rightarrow\left(1-\mathrm{C}^{\prime}\right) \mathrm{zu}^{\prime}\left[\theta_{2}\right]\left(1-\mathrm{F}^{\prime}\left[\left(\Psi_{\mathrm{A}}-\mathrm{Y}\right) \mathrm{t}\right] \mathrm{t}\right)+(1-\mathrm{z}) \mathrm{u}^{\prime}\left[\theta_{3}\right]=0 \\
& \frac{\partial \mathrm{V}}{\partial \mathrm{Y}}=0 \Rightarrow \mathrm{zu}^{\prime}\left[\theta_{2}\right]\left(1-\mathrm{F}^{\prime}\left[\left(\Psi_{\mathrm{A}}-\mathrm{Y}\right) \mathrm{t}\right]\right)+(1-\mathrm{z}) \mathrm{u}^{\prime}\left[\theta_{3}\right]=0
\end{aligned}
$$

These conditions can only hold simultaneously if $\mathrm{C}^{\prime}[]=\mathrm{F}^{\prime}[](1-\mathrm{t}) /\left(1-\mathrm{F}^{\prime}[] \mathrm{t}\right)$ applies, entailing $\mathrm{F}^{\prime}\left[\left(\Psi_{\mathrm{A}}-\mathrm{Y}\right) \mathrm{t}\right] \mathrm{t}<1$ in an interior optimum, as $\mathrm{C}^{\prime}[(\Pi-\Phi) \mathrm{s}]>0$ for $\Pi>\Phi$. Since the marginal fine $C^{\prime}$ for profit tax evasion is independent of the amount of personal income taxes evaded, the optimal declaration of profits is not influenced by personal preferences of the manager, i.e. the curvature of his utility function. However, profit and personal income (tax) declarations are related insofar as that a variation in exogenous variables will generally alter both optimal tax declarations. Assuming a linear fine for personal income tax $\left(F^{\prime \prime}=0\right)$, a higher penalty $F$ for personal income tax evasion can be shown to raise the extent of corporate income misreporting and to reduce the amount of personal income tax evasion. The same prediction is obtained for a rise in the tax rate $\mathrm{t}$ on personal income if the measure of absolute risk aversion is constant. A higher tax rate s on corporate income lowers the extent of corporate and raises that of personal income tax evasion. ${ }^{7}$ Accordingly, the model suggests that if detection probabilities are perfectly correlated, personal and corporate income tax evasion are negatively linked.

The intuition for the findings is the following: a higher fine for personal income tax evasion raises the costs of evasion. Therefore, the personal income declaration is raised. To counteract

\footnotetext{
${ }^{7}$ The respective proofs are to be found in the appendix.
} 
the decrease in expected income the manager amplifies the extent of corporate tax evasion. Given that there are only two states - detection and non-detection - the marginal gains from corporate and personal income tax evasion are identical, as the inspection of the second terms in equations (5') and (6') reveals. However, the costs of evasion are related inversely, as indicated by a comparison of the first terms in equations $\left(5^{\prime}\right)$ and $\left(6^{\prime}\right)$, taking into account $\mathrm{C}^{\prime}>1$ for $\mathrm{Ft}<1$, as $\mathrm{F}^{\prime}>1$. A similar reasoning will apply to a higher tax rate $\mathrm{t}$ on personal income if the income effect of a tax rate change does not invalidate the increase in the fine $\mathrm{F}(\Psi-\mathrm{Y}) \mathrm{t}$, that is if the manager exhibits constant absolute risk aversion. A higher tax rate $\mathrm{s}$ on corporate income ceteris paribus raises the costs of corporate tax evasion $C[(\Pi-\Phi) s]$. Since the marginal costs of corporate tax evasion will have to be constant if according decisions are optimal, corporate tax evasions needs to be raised. However, the gain from declaring personal income rises so that there is again a negative correlation.

The results can be summarised as follows:

\section{Corollary 3}

If the detection probabilities for corporate and personal income tax evasion activities are perfectly correlated, profit tax evasion will be independent of the manager's preferences. Variations in exogenous parameters that change the extent of corporate income tax evasion alter the amount of personal income tax evasion in the opposite direction.

Proposition 2 and Corollary 3 indicate that corporate income tax evasion choices cannot be separated from decisions about personal income tax evasion if the net returns from the former are uncertain or, more generally, vary with the extent of personal income tax evasion. This finding ties in with the suggestion by Yaniv (1995) and a result by Panteghini (2000) regarding the non-separability of, on the one hand, a firm's output or investment decisions and, on the other hand, tax evasion choices in a setting in which output or returns from investment are uncertain. The result is furthermore compatible with, first, Alm's (1988) and Alm and McCallin's (1990) analyses which indicate that the amounts of personal income taxes evaded and avoided, respectively, are not independent and, second, Martinez-Vazquez and Rider's (2005) finding that changes in income or enforcement parameters will have ambiguous consequences on optimal choices as the returns of the two sources of evasion are correlated. 


\section{Conclusions}

Can the determinants of tax base declarations by firms be treated separately from personal income tax evasion choices by the firm's decision makers? The - scarce - empirical evidence suggests that the answer to this question is 'No'. The analysis of this paper has assumed that a risk-averse manager can increase his (expected) income by evading personal income taxes and also by reducing the firm's tax payments below the required or intended level. It is shown that the optimal level of profit tax avoidance is independent of the manager's choices with respect to personal income taxes evaded because the gains and costs from profit tax avoidance are certain. This is the case since the outcome of the personal income tax evasion gamble does not affect the manager's net gain from corporate income tax avoidance. However, if reducing profit tax payments introduces an additional source of uncertainty into the manager's optimisation problem, as in the case of corporate income tax evasion, the respective choices will no longer be independent of personal income tax declarations. The reason for the correlation is that the gains from personal income tax evasion change with the gains form corporate income tax evasion, and vice versa. However, the direction of the correlation between the extent of personal income and corporate income or profit tax evasion is uncertain. This is the case since the manager can, on the one hand, attempt to diversify the risk due to personal income tax evasion activities by reducing corporate income tax evasion. On the other hand, expected income may decline. For the special case of perfectly correlated detection probabilities, the model predicts that variations in exogenous parameters that change the extent of corporate tax evasion alter the amount of personal tax evasion in the opposite direction because the riskdiversification impact prevails.

The results of this paper imply, first, that tax evasion activities by firms can only be separated from personal income tax evasion choices by its decision-makers under special circumstances. Accordingly, the theoretical literature has ignored potentially important determinants of corporate income tax evasion or avoidance. This finding is likely to hold for other taxes levied on and evaded or avoided by firms as well. Second, in empirical analyses of evasion behaviour by firms, the impact of preferences of its decision-makers should be taken into account. Third, while it may well be the case that observing a manager evading taxes provides information on evasion activities by the firm in which he works, the current analytical set-up does not allow possibly to the dismay of tax authorities and the delight of tax-evading managers - to predict and exploit the nature of this relationship. Finally, if tax evasion generates an uncertain net payoff, while tax avoidance is characterised by certain gains and costs, the managers' personal preferences only affect evasion but not avoidance behaviour. 


\section{Appendix - Comparative Statics for the Setting with Perfectly Correlated} Detection Probabilities (Section 4.2)

A linear fine for personal income tax evasion implies $\mathrm{F}^{\prime \prime}=0$ and $\mathrm{F}^{\prime}=\mathrm{F}$. Given optimal choices, the first-order conditions in a setting with perfectly correlated detection probabilities are given by $\left(6^{\prime}\right)$ and $\mathrm{A}:=1-\mathrm{C}^{\prime}[(\Pi-\Phi) \mathrm{s}]-(1-\mathrm{F}) /(1-\mathrm{Ft})=0$. Differentiation, where subscripts indicate partial derivatives, yields: $A_{\Phi}=C^{\prime \prime} s>0, A_{S}=-C^{\prime \prime}(\Pi-\Phi)<0, A_{Y}=0, A_{F}=(1-t) /(1$ $-\mathrm{Ft})^{2}>0, \mathrm{~A}_{\mathrm{t}}=-(1-\mathrm{F}) \mathrm{F} /(1-\mathrm{Ft})^{2}>0, \mathrm{~V}_{\mathrm{YY}}=-\mathrm{t}\left[\mathrm{zu} "\left[\theta_{2}\right](1-\mathrm{F})^{2}+(1-\mathrm{z}) \mathrm{u}^{\prime \prime}\left[\theta_{3}\right]\right]>0, \mathrm{~V}_{\mathrm{Y} \Phi}=$ $\mathrm{V}_{\mathrm{Ys}_{\mathrm{S}}}(\mathrm{s} / \Phi)=-\mu \mathrm{s}\left[\mathrm{zu}^{\prime \prime}\left[\theta_{2}\right](1-\mathrm{F})\left(1-\mathrm{C}^{\prime}\right)(1-\mathrm{Ft})+(1-\mathrm{z}) \mathrm{u}^{\prime \prime}\left[\theta_{3}\right]\right]>0$ as $\left(1-\mathrm{C}^{\prime}\right)(1-\mathrm{Ft})<0, \mathrm{~V}_{\mathrm{Yt}}=-$ $\left[\mathrm{zu}^{\prime \prime}\left[\theta_{2}\right](1-\mathrm{F})\left(\mathrm{Y}+\mathrm{F}(\Psi-\mathrm{Y})+(1-\mathrm{z}) \mathrm{u}^{\prime \prime}\left[\theta_{3}\right] \mathrm{Y}\right]>0\right.$, and $\mathrm{V}_{\mathrm{YF}}=-\mathrm{z}\left[\mathrm{u}^{\prime}\left[\theta_{2}\right]+\mathrm{u}^{\prime \prime}\left[\theta_{2}\right](1-\mathrm{F}) \mathrm{t}(\Psi-\right.$ $\mathrm{Y})]<0$. The change in profit declarations $\Phi$ owing to an increase in any variable $\mathrm{x}, \mathrm{x}=\mathrm{F}, \mathrm{s}, \mathrm{t}$, is given by $d \Phi / d x=-A_{X} / A_{\Phi}$. Making use of the definition of $A$, the first-order condition (6') and the definition of absolute risk-aversion $R_{A}\left(\theta_{i}\right):=-u^{\prime \prime}\left[\theta_{i}\right] / u^{\prime}\left[\theta_{i}\right]>0$, for $i=2,3$, the changes in underreported profits $(\Pi-\Phi)$ and personal income $(\Psi-Y)$ are given by:

$$
\begin{aligned}
& \frac{\mathrm{d}(\Pi-\Phi)}{\mathrm{dF}}=\frac{1-\mathrm{t}}{\mathrm{C}^{\prime \prime} \mathrm{s}(1-\mathrm{Ft})^{2}}>0 \\
& \frac{d(\Psi-Y)}{d F}=\frac{d \Psi}{d F}-\frac{d Y}{d F}=-\mu s\left(1-C^{\prime}\right) \frac{d \Phi}{d F}-\frac{V_{Y} A_{F}-A_{\Phi} V_{Y F}}{A_{\Phi} V_{Y Y}}<0 \\
& \frac{\mathrm{d}(\Pi-\Phi)}{\mathrm{ds}}=\frac{\Pi-\Phi}{\mathrm{s}}<0 \\
& \frac{\mathrm{d}(\Psi-\mathrm{Y})}{\mathrm{ds}}=-\mu \Pi-\frac{\mathrm{dY}}{\mathrm{dt}}=\frac{-(1-\mathrm{t}) \mu \Pi}{\mathrm{V}_{\mathrm{YY}}}\left[\mathrm{zu}^{\prime \prime}\left[\theta_{2}\right](1-\mathrm{F})\left(1-\mathrm{C}^{\prime}\right)+(1-\mathrm{z}) \mathrm{u}^{\prime \prime}\left[\theta_{3}\right]\right]>0 \\
& \frac{\mathrm{d}(\Pi-\Phi)}{\mathrm{dt}}=-\frac{\mathrm{F}\left(1-\mathrm{C}^{\prime}\right)}{\mathrm{C}^{\prime \prime} \mathrm{s}(1-\mathrm{Ft})}>0 \\
& \frac{d(\Psi-Y)}{d t}=-\mu s\left(1-C^{\prime}\right) \frac{d \Phi}{d t}-\frac{d Y}{d t}=\frac{\left(1-C^{\prime}\right) F}{C^{\prime \prime} s(1-F t) V_{Y Y}}\left(\mu s\left(1-C^{\prime}\right) V_{Y Y}+V_{Y} \Phi\right)+\frac{V_{Y t}}{V_{Y Y}} \\
& =\frac{\mu\left(1-\mathrm{C}^{\prime}\right) \mathrm{F}}{\mathrm{C}^{\prime \prime}(1-\mathrm{Ft}) \mathrm{V}_{\mathrm{YY}}}\left[\mathrm{zu}^{\prime \prime}\left[\theta_{2}\right](1-\mathrm{F})\left(1-\mathrm{C}^{\prime}\right)(\mathrm{t}-1)+(1-\mathrm{z}) \mathrm{u}^{\prime \prime}\left[\theta_{3}\right]\left(\left(1-\mathrm{C}^{\prime}\right) \mathrm{t}-1\right)\right]+\frac{\mathrm{V}_{\mathrm{Yt}}}{\mathrm{V}_{\mathrm{YY}}} \\
& =\frac{(1-\mathrm{z}) \mathrm{u}^{\prime}\left[\theta_{3}\right] \mu\left(1-\mathrm{C}^{\prime}\right) \mathrm{F}}{\mathrm{V}_{\mathrm{YY}} \mathrm{C}^{\prime \prime}(1-\mathrm{Ft})}\left(\mathrm{R}_{\mathrm{A}}\left(\theta_{2}\right)\left(1-\mathrm{C}^{\prime}\right)(\mathrm{t}-1)-\mathrm{R}_{\mathrm{A}}\left(\theta_{3}\right)\left(\left(1-\mathrm{C}^{\prime}\right) \mathrm{t}-1\right)\right) \\
& -\frac{(1-\mathrm{z}) \mathrm{u}^{\prime}\left[\theta_{3}\right]\left(\mathrm{R}_{\mathrm{A}}\left(\theta_{2}\right)(\mathrm{Y}+\mathrm{F}(\Psi-\mathrm{Y}))-\mathrm{R}_{\mathrm{A}}\left(\theta_{3}\right) \mathrm{Y}\right)}{\mathrm{V}_{\mathrm{YY}}}
\end{aligned}
$$


For a constant measure of absolute risk aversion $\left(R_{A}\left(\theta_{i}\right)=R_{A}(\theta), i=2,3\right),(A .6)$ collapses to:

$$
\frac{\mathrm{d}(\Psi-\mathrm{Y})}{\mathrm{dt}}=\frac{(1-\mathrm{z}) \mathrm{u}^{\prime}\left[\theta_{3}\right] \mathrm{R}_{\mathrm{A}}(\theta)}{\mathrm{V}_{\mathrm{YY}}}\left[\frac{\mu\left(1-\mathrm{C}^{\prime}\right) \mathrm{FC}^{\prime}}{\mathrm{C}^{\prime \prime}(1-\mathrm{Ft})}-\mathrm{F}(\Psi-\mathrm{Y})\right]<0
$$

\section{References}

Allingham, Michael G. and Agnar Sandmo (1972), Income Tax Evasion: A Theoretical Analysis, Journal of Public Economics 1, 323-338.

Alm, James (1988), Compliance Costs and the Tax Avoidance-Tax Evasion Decision, Public Finance Quarterly 16(1), 31-66.

Alm, James (1999), Tax Compliance and Tax Administration, 741-768, in: Hildreth, W. Bartley and James A. Richardson (eds), Handbook on Taxation, New York, NY: Marcel Dekker, Inc.

Alm, James and Nancy J. McCallin (1990), Tax Avoidance, Tax Evasion, and Portfolio Choice, Public Finance/Finances Publiques 45(2), 193-200.

Andreoni, James, Erard, Brian and Jonathan Feinstein (1998), Tax Compliance, Journal of Economic Literature 36(2), 818-860.

Baldry, Jonathan C. (1987), Income Tax Evasion and the Tax Schedule: Some Experimental Results, Public Finance/ Finances Publiques 42(3), 357-383.

Balestrino, Alessandro and Umberto Galmarini (2003), Imperfect Tax Compliance and the Optimal Provision of Public Goods, Bulletin of Economic Research 55(1), 37-52.

Chen, Kong-Ping and C.Y. Cyrus Chu (2005), Internal Control vs. External Manipulation: a Model of Corporate Income Tax Evasion, Rand Journal of Economics 36(1), 151-164.

Cowell, Frank A. (1990a), Cheating the Government - The Economics of Evasion, MIT Press: Cambridge (Massachusetts) and London.

Cowell, Frank A. (1990b), Tax Sheltering and the Cost of Evasion, Oxford Economic Papers 42(1), 231-243.

Crocker, Keith J. and Joel Slemrod (2005), Corporate Tax Evasion with Agency Costs, Journal of Public Economics 89, 1593-1610.

Joulfaian, David (2000), Corporate Income Tax Evasion and Managerial Preferences, Review of Economics and Statistics 82, 698-701.

Landskroner, Y., Paroush, J. and I. Swary (1990), Tax Evasion and Portfolio Decisions, Public Finance/Finances Publiques 45(3), 409-422.

Lee, Kangoh (1995), Risk-Taking and Business Income Tax Evasion, Public Finance/Finances Publiques 50(1), 106-120.

Lee, Kangoh (1998), Tax Evasion, Monopoly, and Nonneutral Profit Taxes, National Tax Journal 51, 333-338.

Marchese, Carla (2004), Taxation, Black Markets, and Other Unintended Consequences, 237275, in: Backhaus, Jürgen G. and Richard E. Wagner (2004), Handbook of Public Finance, Boston et al.

Marelli, Massimo (1984), On Indirect Tax Evasion, Journal of Public Economics 25, 181-196.

Marelli, Massimo and R. Martina (1988), Tax Evasion and Strategic Behaviour of the Firms, Journal of Public Economics 37, 55-69.

Martinez-Vazquez, Jorge and Mark Rider (2005), Multiple Modes of Tax Evasion: Theory and Evidence, National Tax Journal 68(1), 51-76. 
Panteghini, Paolo M. (2000), Tax Evasion and Entrepreneurial Flexibility, Public Finance Review 28, 199-209.

Slemrod, Joel and Shlomo Yitzhaki (2002), Tax Avoidance, Evasion, and Administration, 1423-1470, in: Auerbach, A. J. and Martin Feldstein (eds), Handbook of Public Economics, Vol. 3, Elsevier: Amsterdam et al.

Wang, Leonard F. S. and John L. Conant (1988), Corporate Tax Evasion and Output Decisions of the Uncertain Monopolist, National Tax Journal 41, 579-581.

Wrede, Matthias (1995), Tax Evasion and Risk-Taking: is Tax Evasion Desirable?, Public Finance/Finances Publiques 50(2), 303-316.

Yaniv, Gideon (1995), A Note on the Tax Evading Firm, National Tax Journal 48, 113-120.

Yaniv, Gideon (1996), Tax Evasion and Monopoly Output Decisions: Note, Public Finance Quarterly 24, 501-505.

Yaniv, Gideon (1999), Tax Evasion, Risky Laundering, and Optimal Deterrence Policy, International Tax and Public Finance 6, 27-38.

Yitzhaki, Shlomo (1974), A Note on Income Tax Evasion: a Theoretical Analysis, Journal of Public Economics 3, 201-202. 